\title{
TIPOLOGI IDEOLOGI RESEPSI AL QURAN DI KALANGAN MASYARAKAT SUMENEP MADURA
}

\author{
Fathurrosyid \\ Institut Ilmu Keislaman Annuqayah (INSTIKA) \\ Email: fathurrosyid090381@gmail.com
}

\begin{abstract}
Islamic teachings in the Quran are fused in the community life of West Pakandangan Village, district Bluto at Sumenep Madura. It is not only expressed through reading and exploring the moral messages, or is treated as magical and powerful objects, but also is an aesthetic reception. For instance using a piece of written verses as accessories at homes, mosques and others. This research is qualitative in nature, employing both literary review and field research. It uses phenomenological analysis and content analysis. The findings show; first, the ideological typology of Quran reception in West Pakandangan involves exegetical, aesthetic and functional receptions. Second, the surface structure of reception symbols presents the religious community. While the deep structure exists in the form of social harmony, social stratification, educational media and pragmatic logical structure on the miracle of Quran. Thirdly, the typology reception of West Pakandangan society in the discourse of Quran and commentary can be categorized as a realist and transformative interpretation, that is dialectic and negotiated interpretation with the social context developed in the community.
\end{abstract}

Ajaran-ajaran Islam yang termuat dalam al Quran sudah menyatu dalam kehidupan masyarakat Desa Pakandangan Barat, Kecamatan Bluto, Kabupaten. Sumenep Madura. Penyatuan tersebut selain diekspresikan dengan cara dibaca dan dikaji pesan-pesan moralnya, diperlakukan sebagai "benda ajaib" yang berkekuatan magic, juga diresepsi secara estetis. Misalnya potongan ayat ditulis dan dijadikan aksesoris rumah, masjid dan lainnya. Penelitian ini berjenis penelitian kualitatif, yaitu penelitian kepustakaan dan penelitian lapangan sekaligus. Analisis yang digunakan adalah analisis fenomenologis dan analisis 
isi. Hasil penelitian ini menyimpulkan; pertama, tipologi ideologi resepsi al Quran di Pakandangan Barat, berupa resepsi eksegetis, resepsi estetis dan resepsi fungsional. Kedua, struktur luar (surface structure) simbolisasi resepsi menunjukkan sebagai masyarakat yang religius. Sementara struktur dalamnya (deep structure) berupa harmonisasi sosial, stratifikasi sosial, media edukatif dan struktur logika pragmatis tentang kemukjizatan al Quran. Ketiga, tipologi resepsi masyarakat Pakandangan Barat dalam diskursus ilmu al Quran dan tafsir dapat dikategorikan sebagai tafsir realis dan transformatif, yaitu tafsir yang berdialektika dan bernegosiasi dengan konteks sosial yang sedang berkembang di masyarakat.

Keywords: the typology; reception and al Quran al-Hayy

\section{Pendahuluan}

Begitu "kitab suci" umat Islam diturunkan ke bumi, salah-satu nama yang seringkali dilabelkan padanya yaitu nama al Quran. Ikhtiar labelisasi tersebut, satu sisi menurut Imam al Suyuti, sebagai binary opposition dengan logika dan tradisi sastra Arab kala itu (al Suyuthi,1414: 141), juga sebagai alat evaluasi untuk memproteksi (protective/al hifdzu) eternalitas, otentisitas dan validitas al Quran, di sisi yang lain. Bentuk protektifikasi ini dilakukan dengan cara dibaca dengan lisan (al sinat) dan ditulis dengan menggunakan pena (al aqlam) (Darraz, 1985: 12), sehingga wajar jika kitab ini lebih populer dinamakan al Quran (Tha'imah, 1399: 76) dari pada nama lain karena ia harus dibaca. Proses-proses tersebut, diyakini oleh para komentator al Quran, mufassir dan penggiat ilmu-ilmu keislaman sebagai "perisai" canggih untuk menjaga dan merawat kitab suci yang diturunkan kepada nabi terakhir, Muhammad bin Abdillah SAW.

Tentu saja, sebagai kitab yang harus dibaca, model-model serta varian bacaan yang diaplikasikannya antara yang satu dengan yang lain berbeda cara sesuai dengan motivasi dan hidden ideologi yang diusung dan yang menungganginya. Motivasi tersebut bisa berupa ekspresi bacaan al Quran yang bertujuan untuk mendapat pahala, sebagai petunjuk teknis dalam kehidupan dan sebagai alat jastifikasi dalam tindakannya (Rofiq, 2004: 3-4). Beberapa varian dan model pembacaan tersebut, disimpulkan sebagai sesuatu yang wajar dan legal. Hal ini disebabkan al Quran diperuntukkan untuk manusia yang berfungsi sebagai "hudan" (petunjuk). Karena itu, tidak heran jika Peter Werenfels menandaskan, bahwa "setiap orang akan mencari sistem teologisnya dalam kitab suci ini, dan (dalam waktu yang sama) ia juga akan menemukan sistem tersebut dengan orientasi tertentu sesuai dengan apa yang dicarinya" (Ziher, 1403: 3). 
Model bacaan yang dieskpresikan dengan motivasi tersebut apabila ditelusuri dan ditilik pada sejarah Islam masa awal, stadion embrionalnya (embryo stadium) sudah pernah, bahkan nyaris dipraktikkan tiap hari pada era nabi dan sahabat. Salah-satu kasus yang bisa diangkat dalam konteks ekpresi bacaan ayat al Quran bermotif petunjuk praktis adalah kisah heroik sahabat Abdullah bin Mas'ud -penulis wahyu dan mufassir era sahabat- di saat beliau sakit menjelang akhir hayatnya. Sahabat senior, Abu Bakar datang membesuknya sembari menawarkan pemberian material. Namun, inisiatif baik Abu Bakar ditolak oleh Abdullah bin Mas'ud, dengan tegas berkata, "Maaf, sayat tidak butuh itu. Karena, sepeninggalku kelak, aku telah mengajarkan suatu surat al Quran kepada putra-putriku yang-jika dibaca secara intensif oleh mereka-tidak akan bisa ditimpa kefakiran selamanya, yaitu surat al Waqi'ah" (al Qurthubi, 1423: 194).

Kisah heroik di atas bisa tentu bisa dijadikan salah-satu indikator konkrit bahwa resepsi fungsional-praktikal terhadap ayat-ayat suci al Quran di tingkat sahabat telah dilakukan secara intensif dan masif. Mereka tiada hentihentinya membaca al Quran di setiap hari dan malam, sehingga suasananya terdengar seakan-akan seperti dawai lebah ( $k$ a dawiyyi al-nahli) yang mengaung setiap saat (Syuhbah, 1423: 261). Praktik dan resepsi yang demikian, terus mengalami transmisi, transformasi dan kaderisasi kepada generasigenerasi berikutnya, utamanya ditingkat tabi'in hingga pada generasi kita, termasuk di dalamnya praktik dan resepsi masyarakat Indonesia terhadap al Quran, utamanya masyarakat Madura yang ada di Kabupaten Sumenep, Desa Pakandangan Barat.

Pakandangan Barat, secara geografis, merupakan suatu desa yang terletak di perlintasan antar Kota Pamekasan dan Kota Sumenep, sehingga sangat strategis dan kondusif untuk mengakses isu-isu keberagamaan baik yang berskala nasional maupun trans-nasional. Di samping itu, desa tersebut merupakan jantung "kota santri" yang tidak hanya berbasis pada disiplin keilmuan tradisional, tetapi juga disiplin keilmuan modern, semisal Pondok Pesantren (PP) Nurul Huda Pakandangan. Kedua basis pendidikan tersebut, baik pada diri sang kyai, tokoh masyarakat maupun para alumninya, jelas mempunyai dampak psikologis yang sangat signifikan dalam menghadapi berbagai isu-isu keagamaan.

Ajaran-ajaran Islam yang termuat dalam al Quran sudah menyatu sedemikian kuat sehingga akhirnya berfungsi sebagai inti kebudayaan yang memuat ajaran moral dan etika yang menyelimuti seluruh sendi kehidupan masyarakat. Dalam konteks yang demikian, maka wajar jika dalam tradisi 
masyarakat Pakandangan Barat, al Quran menjadi sebuah kitab suci yang inhern dan built-in dalam kehidupan mereka, bahkan sudah mendarah daging dalam kehidupan mereka itu sendiri, sehingga pergaulan masyarakat dengan al Quran terjadi begitu dekat, hangat, intensif, interaktif dan dialogis.

Contoh menarik yang bisa diangkat terkait pergaulan masyarakat Pakandangan Barat dengan al Quran, selain diekspresikan dengan cara dibaca dan dikaji untuk dipahami pesan-pesan moralnya, masyarakat Pakandangan Barat juga memperlakukan al Quran sebagai "benda ajaib” yang punya kekuatan magic. Karena itu, potongan ayat-ayat suci dijadikan azimat sebagai penglaris perniagaan, kekebalan tubuh dan penolak kejahatan. Kecuali itu, surat-surat tertentu dalam al Quran juga dijadikan surat "idaman" yang dibaca dalam acara tahlilan, tasyakuran perkawinan dan kehamilan serta dibaca pada acara slametan. Selain ekspresi-ekspresi di atas, al Quran juga diresepsi secara estetis, misalnya potongan ayat ditulis dan dijadikan aksesoris rumah, masjid dan di tempat suci lainnya atau bisa juga al Quran dibaca secara murattal dalam acara-acara tertentu dan juga potongan ayat diterjemahkan menjadi bait-bait lagu.

Fenomena pergaulan, interaksi dan resepsi masyarakat Pakandangan Barat terhadap al Quran, sebagaiama paparan di atas, dalam kajian metodologi ilmu tafsir disebut "al Quran al hayy” atau "Studi Living Quran" (Mansyur, 2007: 8). Berdasarkan fenomena tersebut, penelitian ini bertujuan untuk mengetahui tipologi dan simbolisasi varian resepsi masyarakat Desa Pakandangan Barat terhadap al Quran. Selain itu, juga bertujuan untuk mengetahui posisi simbolisasi resepsi dalam diskursus ilmu al Quran dan tafsir.

\section{Resepsi al Quran; Definisi dan Asumsi Dasarnya}

Secara etimologis, kata "resepsi" berasal dari bahasa Latin yaitu recipere yang diartikan sebagai penerimaan atau penyambutan pembaca (Ratna, 2009: 22). Sedangkan definisi resepsi secara terminologis yaitu sebagai ilmu keindahan yang didasarkan pada respon pembaca terhadap karya sastra (Pradopo, 2007: 7). Dari definisi tersebut dapat disimpulkan bahwa, resepsi merupakan disiplin ilmu yang mengkaji peran pembaca dalam merespon, memberikan reaksi, dan menyambut karya sastra.

Pada awalnya, resepsi memang merupakan disiplin ilmu yang mengkaji tentang peran pembaca terhadap suatu karya. Hal ini dikarenakan karya sastra ditujukan kepada kepentingan pembaca sebagai penikmat dan konsumen karya sastra. Dalam aktivitas mengkonsumsi tersebut, pembaca menentukan makna dan nilai dari karya sastra, sehingga karya sastra mempunyai nilai 
karena ada pembaca yang memberikan nilai. Dengan demikian, teori resepsi ini membicarakan peranan pembaca dalam menyambut suatu karya. Dalam memandang suatu karya, faktor pembaca sangat menentukan karena makna teks, antara lain, ditentukan oleh peran pembaca. Makna teks bergantung pada situasi historis pembaca, dan sebuah teks hanya dapat mempunyai makna setelah teks itu dibaca (Iser, 1978: 20).

Dari definisi di atas, jika dikombinasikan menjadi resepsi al Quran, maka definisi secara terminologis berarti kajian tentang sambutan pembaca terhadap ayat-ayat suci al Quran. Sambutan tersebut bisa berupa cara masyarakat dalam menafsirkan pesan ayat-ayatnya, cara masyarakat mengaplikasikan ajaran moralnya serta cara masyarakat membaca dan melantunkan ayat-ayatnya. Dengan demikian, pergaulan dan interaksi pembaca dengan al Quran merupakan konsentrasi dari kajian resepsi ini, sehingga implikasi dari kajian tersebut akan memberikan kontribusi tentang ciri khas dan tipologi masyarakat dalam bergaul dengan al Quran.

Sementara itu, jika teori resepsi pada dasarnya merupakan teori yang mengkaji peran dan respon pembaca terhadap suatu karya sastra, maka persoalan penting yang harus diselesaikan apakah al Quran merupakan karya sastra? Menurut ahli sastra, suatu karya dapat digolongkan sebagai karya sastra yaitu apabila mempunyai tiga elemen literariness (aspek sastra) sebagai berikut:

1. Estetika rima dan irama.

2. Defamiliarisasi, yaitu kondisi psikologi pembaca yang mengalami ketakjuban setelah mengkonsumsi karya tersebut.

3. Reinterpretasi, yaitu kuriositas pembaca karya sastra untuk melakukan reinterpretasi terhadap karya sastra yang telah dinikmatinya (Rahman, 2004: 218).

Dari ketiga elemen literariness di atas, kitab suci al Quran yang mengggunakan media bahasa Arab juga kaya dengan elemen tersebut, misalnya, elemen pertama yang berbasis pada rima dan irama. Demikian pula, pada elemen defamiliarisasi di dalam diri si pembaca. Begitu seseorang membaca al Quran, maka otomatis ia akan takjub padanya. Sayyid Qutb menyebut proses ketakjuban ini dengan istilah mashurun bi al Quran (tersihir oleh al Quran), sebagaimana kejadian yang dialami oleh Umar bin Khattab (Baihaqi, 1408: 199 dan Muslim, 1426: 45). Kecuali itu, proses reinterpretasi sebagai konsekuensi dari elemen ketiga juga tampak nyata dalam al Quran. Proses reinterpretasi dalam konteks ini adalah respon pembaca atau pendengar terhadap kedua elemen di atas, sehingga dalam kajian keislaman, banyak orang yang tertarik 
untuk mengakaji aspek estetika al Quran, aspek retorika dan sebagainya.

\section{Resepsi al Quran: Ekspresi Cinta Komunitas Muslim}

Ketika al Quran diturunkan, maka Rasulullah adalah sosok yang paling "bertanggung jawab" untuk menyampaikan pesan-pesan moral yang tersurat dan tersirat di dalamnya. Karena itu, sebagai pembawa risalah, Rasulullah diberi otoritas penuh oleh Tuhan untuk menjelaskan pesan wahyu kepada umatnya ketika mereka mendapatkan kesulitan dalam memahami teks wahyu. Berangkat dari basis data tersebut, maka Rasulullah adalah orang pertama yang meresepsi al Quran secara eksegesis-interpretatif, karena beliau merupakan sosok yang paling otoritatif dalam menginterpretasikan pesan-pesan al Quran. Sekalipun demikian, betapa pun Rasulullah sangat aktif terlibat dalam penafsiran al Quran, namun tidak semua ayat al Quran ditafsirkan beliau (al Dzahabi, tt: 53).

Selain meresepsi al Quransecara eksegesis, Rasulullah dalam kondisi tertentu juga meresepsi al Quran secara fungsional. Dalam konteks ini, beliau menjadikan ayat-ayat suci al Quran sebagai terapi atau yang populer dengan sebutan ruqyah. Misalnya, Rasulullah pernah membaca surat mu'awwizatain, kemudian ditiupkan pada telapak tangannya dan digosokkan pada tubuhnya pada saat beliau sakit sebelum kewafatannya (al Bukhari, 1407: 170).

Pada umumnya, para sahabat dapat menafsirkan al Quran, sebab mereka adalah orang-orang yang langsung mendapatkan pendidikan dari sumber paling otoritatif dalam menginterpretasi al Quran (baca: Nabi Muhammad SAW), yang selalu berusaha memahami, mengerti, memikirkan, merenungi wahyu Ilahi untuk mengeluarkan mutiara hikmah yang terkandung di dalamnya (Ja'far, 2007: 446-7). Faktor-faktor inilah yang kemudian menjadikan mereka sebagai orang yang faham dan mengerti tentang kehendak Tuhan dalam firman-firmannya. Di samping karena memang al Quran diturunkan dengan menggunakan bahasa mereka sendiri, sehingga dalam sejarah, terdapat sepuluh orang yang ahli dalam bidang tafsir, yaitu: khalifah yang empat, Ibn】 Mas'đd, Ibn 'Abbas, Ubayy bin Ka'b, Zaid bin Thabit, Abu Musa al-Ash'ari dan Abdullah ibn Zubair (al Qaththan, 1973: 343).

Setelah era sahabat, tradisi penafsiran dilanjutkan oleh generasi para tabi'in dengan pola yang relatif sama. Memang ada hal yang membedakan antara tradisi penafsiran era sahabat dengan era tabi'in. Di era sahabat belum muncul sektarianisme aliran-aliran tafsir yang tajam, sementara di era tabi'in sudah muncul aliran-aliran tafsir berdasarkan kawasan. Bahkan mulai muncul 
pula sektarianisme ideologi, seperti yang dinisbatkan kepada Imam Qatadah ibn Di'amah al-Sadusi (w. $117 \mathrm{H}$ ) yang dinilai berbau aliran Qadariyah, karena terlalu dalam ketika membahas masalah qada-qadar (al Dzahabi, tt.: 131).

\section{Metode Penelitian}

Penelitian ini berjenis penelitian kualitatif, yaitu penelitian kepustakaan (library research) dan penelitian lapangan (field research) sekaligus (Surakhmad, 1990: 182). Maksud dari penelitian kualitatif adalah penelitian yang menghasilkan data deskriptif berupa kata-kata tertulis atau lisan dari orang-orang dan perilaku yang diamati (Moleong, 2009: 4). Dikatakan demikian, karena penelitian ini akan mengkaji fenomena resepsi masyarakat Desa Pakandangan Barat terhadap al Quran.

Semua data yang digunakan dalam penelitian ini dikumpulkan dengan teknik-teknik observasi, interview dan dokumentasi (Arikunto, 1993: 117). Artinya, melalui observasi dan dokumentasi, peneliti akan mengamati dan mencatat perilaku resepsi masyarakat Pakandangan Barat terhadap al Quran. Adapun melalui interview peneliti akan mencari alasan dan jawaban mengapa al Quran diresepsi secara eksegetis, estetis dan fungsional.

Setelah data terhimpun selanjutnya dilakukan beberapan tahap analisis data, baik data tertulis maupun rekaman hasil wawancara dengan tetap memegang prinsip triangulasi secara konsisten (Bungin, 2006: 186-194). Analisis dalam konteks ini menggunakan analisis fenomenologi yang digagas oleh Edmund Husserl, yaitu mempelajari bagaimana fenomena manusia dialami dalam struktur kesadaran manusia dalam tindakan yang melibatkan aspek kognitif dan persepsi (Annisa, 2012: 43). Dalam konteks ini, fenomena yang terjadi di masyarakat Desa Pakandangan Barat tidak hanya dipandang sebagai gejala yang tampak dari kulit luarnya saja, tetapi berusaha memahami dan menggali makna dibalik gejala resepsi tersebut secara totalitas.

Adapun subjek penelitian terdiri dari tokoh masyarakat dan seluruh warga Desa Pakandangan Barat. Adapun teknik pengambilan sumber data tesebut dilakukan dengan cara snowball sampling yaitu penggalian data melalui wawancara mendalam dari satu responden ke responden lainnya dan seterusnya sampai peneliti tidak menemukan informasi baru lagi. Arinya, teknik tersebut dilakukan dengan cara menentukan tokoh kunci terlebih dahulu yang banyak mengetahui tentang tipologi resepsi al Quran di kalangan masyarakat Desa Pakandangan Barat. Selanjutnya, dilakukan pengambilan data pada subjek-subjek yang lain, sehingga akan diperoleh data yang utuh, totalitas dan komprehensif. 


\section{Pembahasan}

Kondisi Geografis, Sosial dan Ekonomi

Desa Pakandangan Barat merupakan salah-satu dari 20 (dua puluh) desa yang ada di Kecamatan Bluto, Kabupatan Sumenep. Desa ini, secara geografis terletak di ujung paling barat dari Kecamatan Bluto yang terdiri dari 20 desa. Dari data di atas, dapat disimpulkan bahwa luas wilayah Desa Pakandangan Barat seluas 4. 255. $708 \mathrm{~km}$. Adapun jumlah total dusun yang ada di Desa Pakandangan Barat adalah 5 (lima) dusun, yaitu Dusun Pesisir, Dusun Tegal, Dusun Sumber Nangka, Dusun Brumbung, dan Dusun Jeruk.

Secara umum, kondisi dan keadaan demografi (kependudukan) Desa Pakandangan Barat merupakan desa yang padat penduduk. Jumlah total penduduk Desa Pakandangan Barat sebanyak 3.890 yang terdiri dari laki-laki sebanyak 1.898 dan penduduk perempuan sebanyak 1.992. Jumlah tersebut berdasarkan keadaan demografi yang ada di desa Pakandangan Barat. Sedangkan kondisi perekonomian masyarakat Desa Pakandangan Barat cukup beragam. Dalam konteks ini terdapat tujuh jenis perkonomian yang meliputi pertanian, tambang, industri, konstruksi, perdagangan, tranportasi dan jasa.

Pertanian Masyarakat Pakadangan Barat meliputi pertanian pangan sebanyak 415 orang, perkebunan 238 orang dan peternakan 114 orang. Adapun pekerja tambang atau galian di Desa Pakandangan terkonsentrasi terdapat 100 orang. Sementara dalam bidang industri di Desa Pakandangan Barat tidak ada yang menekuni. Sedangkan warga yang bergelut dalam bidang konstruksi bangunan ini sebanyak 256 orang. Perdagangan ditekuni oleh 345 orang, tranportasi ditekuni oleh 167 orang, bisnis jasa dikerjakan dan ditekuni oleh 534 orang dan jenis nelayan diminati oleh warga yang menetap di dusun pesisir sebanyak 122 orang.

\section{Tipologi Resepsi Masyarakat Pakandangan Barat terhadap al Quran}

1. Ayat sebagai Teks Khutbah: Resepsi Eksegesis terhadap al Quran

Kehadiran al Quran di mata masyarakat Pakandangan Barat mendapat apreseasi positif. Apresiasi ini terlihat ketika warga masyarakat Pakandangan mampu meresepsi al Quran secara eksegetis; yaitu al Quran dibaca, dipahami dan diajarkan. Salah-satu indikasi konkrit ke arah resepsi eksegetis tersebut yaitu adanya buku teks khutbah Idul Fitri yang ditulis dan disampaikan oleh KH. Saifurrahman, Pengasuh PP. Nurul Huda, Dusun Pesisir Pakandangan Barat, di Masjid Agung Sumenep, tepat pada tanggal 1 Syawwal 1428 H/ Oktober 2007 M. Teks khutbah tersebut selengkapnya adalah sebagai berikut: 
Selain ibadah yang berdimensi vertikal, Islam juga mengajarkan ibadah yang berdimensi horizontal artinya bahwa ibadah apapun yang dilakukannya demi Allah telah juga dihubungkannya dengan mashlahat kehidupan sesama ummat manusia. Rasa ibadah yang tinggi di dalam dirinya telah membangkitkan rasa solidaritas sosial yang tinggi, telah menghidupkan rasa kedermawanan sosial yang luar biasa, telah membentuk watak yang mulia sehingga dia pandai juga memuliakan dan menghormati orang lain. Dari sikap ubudiah sosial yang tinggi ini lahirlah tradisi shilaturrahim, menghargai orang lain tanpa membedakan ras, tanpa melihat strata sosial, ekonomi, golongan bahkan partai politik sekalipun. Hilang dari dirinya sikap egosentris, egoistik, sikap kikir, sikap mementingkan diri sendiri, sikap mungkar, jahat kepada orang, sikap khianat terhadap amanat yang dipercayakan di atas pundaknya. Jadilah ia manusia mukmin seutuhnya yang penuh "iimaanan wah tisaaban". Tidak sebagaimana firman Allah:

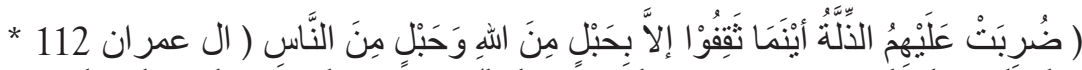

Mereka akan ditimpa kenistaan/kehinaan di mana saja mereka berađa, kecuali dengan menyambung tali hubungan dengan Allah (vertikal) dan tali hubungan dengan manusia (horizontal).

Potongan ayat di atas, menurut K.H. Saifurrahman Nawawi, merupakan bentuk deklarasi dari Allah, bahwa menjadi muslim sejati harus mampu bisa melaksanakan kegiatan ibadah yang bersifat bidimensional secara simultan antar ibadah vertikal dan horizontal. Artinya, kesalehan individual saja tidak cukup dijadikan indikasi ketinggian spritualitas seseorang tanpa diimbangi dengan kesalehan sosial. Sebab, Islam adalah agama yang pro kemanusiaan dengan jargon sebagai agama yang "rahmatan li al-alamin".

Dengan demikian, khutbah yang disampaikan oleh KH. Saifurrahman dengan merujuk kepada QS Ali Imran: 112 merupakan bukti resepsi al Quran secara eksegetis. al Quran tidak menjadi sebuah kitab suci yang berwujud "benda mati". Al Quran tidak menjadi kitab suci yang hanya dibaca, dipuja-puji, dikagumi dan disakralkan begitu saja, tetapi juga ditafsirkan, diinterpretasikan dan dipahami pesan-pesannya secara mendalam.

1. Ayat sebagai Aksesoris Masjid dan Rumah: Resepsi Estetis terhadap al Quran

Desa Pakandangan Barat merupakan desa perlintasan menuju kota Sumenep dan Pamekasan. Jika melintasi desa ini, maka akan terlihat dua masjid berjejer yang terletak di pinggir jalan raya, yaitu Masjid al Fu'adi dan Masjid al Hidayah. Masjid pertama berlokasi di daerah Dusun Pesisir, 
sementara masjid yang disebutkan berikutnya terletak di Dusun Buddeggan. Kehadiran dua masjid ini tentu untuk mempermudah setiap pengguna jalan yang melintasi daerah tersebut untuk beristirahat dan sholat.

Kehadiran al Quran bagi warga Pesisir mendapat resepsi estetis. Hal ini tampak terlihat pada ornamen-ornamen yang ada dalam Masjid al-Fuadi. Begitu memasuki masjid tersebut, maka akan disuguhi berbagai potongan ayat-ayat al Quran yang menghiasi seluruh dinding gedung masjid. Tulisan ayat al Quran ditampilkan di gedung sebelah barat masjid berjumlah 10 surat, yaitu: QS Ali Imran: 133; QS al Taubah: 108; QS al Isra': 78; QS al Baqarah: 144; QS al Baqarah:114; QS al Baqarah: 238-239; QS Ibrahim: 40-41; QS al Ma'arij: 19-23; QS al An'am: 162-163 dan QS al Hasyr: 22. Ayat yang terakhir ini ditulis dalam bentuk bulat berada di depan imam shalat.

Berbeda dengan Masjid al Fu'adi yang lebih menonjolkan tulisan potongan ayat al Quran, di Dusun Buddeggen, Masjid al Hikmah tidak ada satupun aksesoris yang terdapat dalam masjid tersebut. Hanya ditemukan satu tulisan berupa hadits nabi yang tertulis melingkar di atas tempat imam shalat. Hadits tersebut yaitu "Shalat al Jama'at Afdalu min Shalat al Fadzdzi bi Sab'in wa 'Isyrina Darajatan (shalat berjemaah lebih utama dari pada shalat sendirian sebanyak dua puluh derajat)".

Sementara itu, ayat-ayat suci al Quran juga ditemukan di Masjid al Falah, Dusun Tegal. Tepat di sebelah barat, ayat al Quran yang disajikan yaitu QS al Taubah: 18, sementara bagian sebelah utara tertulis QS al An'am: 162-163 dan bagian sebelah selatan QS al Taubah: 108. Semua ayat tersebut ditulis menggunakan kaligrafi berbentuk khat tsuluts di atas dasar warna hijau dengan tinta warna kuning mas.

Resepsi masyarakat Pakandangan Barat terhadap al Quran dalam bentuk estetis yang dituliskan di dinding masjid merupakan simbolisasi yang bernilai spritual. Dalam konteks ini, K. Muzanni (38 th), pengasuh Lembaga Pendidikan Nurus Sa'adah, menyatakan bahwa semua tulisan kaligrafi yang ditaruh di dinding masjid tidak saja sebagai bentuk seni keindahan, tetapi yang paling penting, tulisan-tulisan tersebut dalam rangka memberikan pencerahan spritual kepada masyarakat. Artinya, ketika seseorang melihat ayat tersebut, maka hatinya akan tergugah, seakan-akan ayat itu memberikan peringatan kepada pembaca.

Selain fenomena di atas, masyarakat Desa Pakandangan Barat, terutama di Dusun Pesisir, juga mempunyai tradisi menuliskan potongan ayat-ayat al 
Quran di rumahnya. Bentuk tulisan ayat-ayat tersebut bermacam-macam; ada yang ditulis langsung ke dinding rumahnya menggunakan cat pewarna, ada juga yang ditulis menggunakan aksesoris pigura serta ada pula yang ditulis menggunakan gabus. Tata letak tulisan ayat-ayat al Quran juga bermacammacam sesuai selera dan artistik tempatnya. Ada yang diletakkan di ruang tamu, kamar utama serta ada pula yang ditulis dan ditempel di dinding luar rumah.

Adapun tema atau substansi ayat yang ditulis di dinding tersebut juga beragam;

Tema kewajiban melakukan wisata religi ibadah haji yang mengutip QS Ali Imran: 197; QS al Baqarah: 196, serta juga kutiipan potongan QS al Baqarah: 158. Semua koleksi ayat-ayat wisata religi ibadah haji tersebut biasanya banyak tersebar dan beredar di setiap rumah warga yang mempunyai kesempatan menunaikan ibadah haji ke Baitullah, Mekkah al Mukarramah.

Tema pernikahan. Tradisi penulisan potongan ayat al Quran terkait tema pernikahan ini sering kali mengutip QS al Nisa': 19; QS al Rum: 21; QS al Nisa': 21 dan QS al Tahrim: 6. Hanya saja, tradisi penulisan ayat-ayat pernikahan tersebut, biasanya ditulis tidak permanen. Artinya, tulisan potongan ayat itu sekedar dijadikan aksesoris dan penghias di dinding rumah dalam rangka menyelenggarakan resepsi pernikahan.

Tema teologis-spritual dan sosial. Warga masyarakat Pakandangan Barat juga menjadikan tradisi menghias rumahnya dengan tulisan-tulisan yang bernuansa spritual teologis. Ayat yang sering dipajang dan diletakkan di dinding rumahnya merujuk kepada potongan ayat dalam QS al Baqarah: 255 yang populer dengan sebutan Ayat Kursi. Potongan ayat ini beredar di masyarakat luas, sehingga bagi warga Pakandangan tidak perlu repot melukis sendiri, tetapi cukup membeli di pasar atau di toko-toko aksesoris yang menyediakan kaligrafi Arab.

3. Ayat sebagai Insturmen Ritus dan Mistis: Resepsi Fungsional terhadap al Quran

Masyarakat Pakandangan Barat, dalam praktik kehidupannya seharisehari selain meresepsi al Quran secara eksegetis dan estetis, ternyata juga meresepsi al Quran secara fungsional di mana kehadiran al Quran dijadikan sebagai benda yang mempunyai kekuatan magis. Potongan ayat-ayat al Quran apabila dibaca secara rutin dan konsisten, baik waktu dan tempatnya, maka akan mendatangkan kekuatan yang bersifat adikodrati, misalnya, kekebalan tubuh, bisa membuka gembok atau membuka pintu yang terkunci rapat, serta juga bisa menjadikan tangan mempunyai nilai berat satu ton, sebagaimana 
Arkab/P. Linda 36 th, salah-satu warga dusun Tegal.

Doa-doa tersebut, setelah penulis kroscek ternyata merujuk dan mengambil dari potongan ayat al Quran yang berasal dari QS al Buruj: 20-22. Menurut pengakuan Arkab, bahwa doa (ayat) ini berfungsi untuk memberikan kekuatan pada tangan sehingga bisa membuka gembok atau pintu yang terkunci rapat. Ayat ini dibaca dengan ritual dan syarat tertentu; yaitu dibaca selama tiga malam pada waktu sekitar jam 12 malam sebanyak 113 kali sembari berpuasa pada siang harinya. Selain doa di tersebut, ada juga ayat-ayat al Quran yang berfungsi untuk menggetarkan dan membuat ciut nyali musuh. Ayat ini merujuk pada QS Muhammad: 8-9 dan harus dibaca istiqamah pada tiap malam Jum'at Legi sebanyak 557. Kemudian, setelah berpapasan dengan musuh, maka ayat ini dibacakan pada debu dan dilemparkan pada musuh.

Dari beberapa keterangan di atas, masyarakat Pakandangan Barat mempunyai keyakinan bahwa kehadiran al Quran tidak saja sebagai kitab petunjuk (hudan), tetapi juga berfungsi secara fungsional yang mempunyai kekuatan mistis. Hal ini, menurut K. Muzanni, al Quran sendiri memproklamirkan dirinya secara gamblang sebagai syifa' li al nas dan syifa' lima fi al shudur. Karena itu, ayatayat suci al Quran juga dijadikan amaliyah, wirid dan dzikir untuk mengusir roh jahat, semisal jin dan fenomena mistis lainnya serta juga dijadikan jimat untuk penglaris dagangan dan sebagainya.

Selain diresepsi sebagai instrumen mistis, masyarakat Pakandangan Barat juga meresepsi al Quran sebagai instrumen ritus atau slametan. Di dalam tradisi Jawa, upacara yang terkait dengan kehidupan dikonsepsikan oleh para ahli antropologi sebagai upacara lingkaran hidup (rites of the life cycle) yang dikonsepsikan oleh orang sebagai slametan, yaitu suatu upacara makan bersama makanan yang telah diberi doa sebelum dibagi-bagikan. Slametan ditujukan agar tidak ada gangguan apa pun di dalam kehidupan manusia (Kodiran, 1975: 340). Dengan demikian, fungsi dan manfaat dari slametan merupakan kombinasi harmonisasi yang tidak hanya terjadi antara sesama makhluk hidup, tetapi juga bermakna harmonisasi antara kekuatan natural dan supranatural, antara mikrokosmos dan makrokosmos, antara kekuatan kodrati dan adikodrati, antara kekuatan manusia dan makhluk halus dan lain sebagainya (Syam, 2009: 146).

Masyarakat yang ada di Desa Pakandangan juga mempunyai tradisi yang tidak jauh berbeda. Salah-satu slametan yang sudah menjadi tradisi di Desa Pakandangan yaitu ritual pelet kandung. Maksud pelet kandung secara terminologis adalah tata cara dan tata upacara yang dilaksanakan ketika kandungan seorang 
wanita mencapai usia empat bulan dan atau tujuh bulan (Pringgawidagda, 2003: 1). Ritual atau upacara pelet kandung ini, di mata masyarakat Pakandangan Barat dimaksudkan sebagai media permohonan kepada Allah agar diberikan barokah kemudahan dalam melahirkan. Bagi warga Pakandangan, proses persalinan yang mudah dan gampang, merupakan impian setiap pasangan suami-isteri. Karena itu, ritual pelet kandung merupakan momentum "ampuh" agar seorang ibu diberikan kemudahan dalam melahirkan, sebagaimana pengalaman yang dialami oleh seorang hamba Allah bernama Hannah binti Faqud yang melahirkan Siti Maryam.

Kecuali itu, dengan media ritual pelet kandung tersebut, secara psikologis diharapakan dapat memberikan efek positif terhadap kepribadian bayi setelah terlahir ke dunia kelak. Profil kepribadian lelaki yang bernama Yusuf dan perempuan bernama Maryam merupakan impian setiap pasutri terhadap bayi yang dilahirkannya. Itulah sebabnya, di dalam ritual pelet kandung tersebut, masyarakat Pakandangan menjadikan QS Yusuf: 01-111 dan QS Maryam: 0198 sebagai referensi untuk membentuk karakter dan kepribadian anak seperti Yusuf dan Maryam. K. Muzanni 42 th, menjelaskan bahwa, dipilihnya bacaan Surat Yusuf dan Maryam dalam tradisi pelet kandung merupakan doa kepada Allah agar nantinya diberikan karunia seorang anak yang berkepribadian seperti Yusuf jika bayi yang dilahirkannya seorang laki-laki, dan juga seperti Maryam jika melahrikan bayi seorang perempuan.

Selain dijadikan sebagai media doa dalam pelet kandung, masyarakat Pakandangan Barat juga mempunyai tradisi menjadikan al Quran yang berfungsi sebagai kitab suci penolak balak dan pengusir roh jahat. Dalam konteks keyakinan semacam ini, maka solusi yang paling tepat adalah mengadakan Rokat Pakarangan. Tradisi Rokat Pakarangan merupakan ritual yang dilaksanakan pada setiap awal tahun Hijriah, yaitu bulan Muharram. Tradisi ini dimaksudkan sebagai media memohon perlindungan kepada Allah agar penghuni rumah beserta lokasi yang di tempatinya tidak diganggu oleh makhluk halus, jin dan roh-roh jahat lainnya. Karena itu, mereka membaca surat-surat pilihan dari kitab suci al Quran yang populer dengan sebutan Munjiyat Azimah yang terdiri dari surat Yasin, al Waqi'ah, al Mulk, al Dukhan, al Sajadah dan al Buruj.

Selain itu, al Quran juga dijadikan bacaan ritual harian (awrad alyaumiyyah) dalam bilangan tertentu untuk memperoleh kemuliaan, keberuntungan dan keselamatan dengan cara riyadlah. Kegiatan ini biasanya dilakukan oleh warga ketika mereka mempunyai acara atau hajatan teretntu, misalnya hajatan bangun 
rumah, menikahkan putra-putrinya dan sebagainya. Dalam konteks ini, biasanya masyarakat membaca surat Yasin sebanyak 41 kali dalam satu majlis.

Masyarakat Pakandangan Barat juga mempunyai tradisi membaca ayatayat al Quran dalam forum-forum seremonial, tadarrus, khataman, tahlilan, istighotsah, walimah, dan hajatan. Demikian pula, masyarakat juga menjadikan al Quran sebagai ritus yang dilaksanakan secara rutin, yaitu kegiatan khatmil quran pada setiap malam Jum'at Legi di Masjid al Fuadi, Dusun Pesisir. Kegiatan ini dimulai pada hari Kamis pagi dengan membaca surat al Fatihah, kemudian dilanjutkan pada surat-surat berikutnya, hingga berkahir pada Juz ke-29 pada sore harinya. Setelah usai menjalankan shalat berjemaa'ah maghrib, kegiatan ini dilanjutkan dengan membaca al Quran juz ke-30 nya disertai dengan bacaa'an doa khatmil quran.

\section{Tradisi Resepsi al Quran: Pergumulan antara Motivasi dan Simbol}

Resepsi masyarakat Pakandangan Barat terhadap ayat-ayat al Quran telah diwujudkan dalam beragam bentuk, mulai dari resepsi eksegetis, resepsi estetis dan resepsi fungsional. Resepsi ini dalam kajian antropologi budaya merupakan upaya simbolisasi yang dilakukan oleh warga Pakandangan terhadap al Quran. Tentu saja, sebagai suatu simbol, terdapat beberapa lapisan makna yang perlu dibongkar untuk mengetahui endapan-endapan ideologi yang terapung di dalamnya.

Interpretasi terhadap simbolisasi tersebut bisa dilakukan dengan cara melihat struktur luar (surface structure) dan struktur dalam (deep structure). Struktur luar yang dimaksudkan adalah tradisi masyarakat Pakandangan Barat yang memperlakukan al Quran diresepsi secara eksegetis (dipahami dan ditafsirkan), estetis (dijadikan ornamen seni kaligrafi) dan fungsional (dijadikan instrumen mistis dan ritus). Sedangkan struktur dalamnya yaitu ideologi yang dibangun oleh warga terkait simbolisasi ayat-ayat al Quran dalam aktivitas kesehariannya.

Simbolisasi ayat-ayat al Quran yang diresepsi dengan beragam bentuk, interpretasi terhadap struktur luarnya (surface structure) menunjukkan bahwa warga Pakandangan Barat merupakan masyarakat yang religius dan spritualis. Perilaku religiusitas ini disebabkan kehadiran al Quran tidak hanya dijadikan sebagai sumber pemikiran, bacaan dalam ritual, ornamen kesenian, tetapi juga dijadikan sebagai sarana kekuatan supranatural. Artinya, semua perilaku dan tindakan yang dilakukan oleh masyarakat Pakandangan semuanya mengacu dan merujuk kepada al Quran. Warga setempat memposisikan al Quran 
sebagai konsultan dalam aktivitas kesehariannya. Dengan demikian, al Quran sebagai kitab suci benar-benar telah menjadi kitab yang inheren, built in dan mendarah daging dalam kehidupan mereka.

Sementara interpretasi terhadap simbolisasi struktur dalamnya (deep structure) bisa di-break down dari tiga hal;

Resepsi eksegetis. Teks khutbah Idul Fitri yang disampaikan oleh KH. Saifurrahman Nawawi dengan mengutip QS Ali Imran: 112 merupakan pesan moral kepada publik tentang solidairas dan kohesivitas sosial. Hal ini disebabkan, audien serta mitra tuturnya adalah masyarakat perkotaan mengingat teks khutbah tersebut disampaikan di Masjid Jami' Sumenep. Masyarakat perkotaan merupakan masyarakat yang lebih mengedepankan kehidupan individual dari pada masyarakat pedesaan.

Resepsi estetis. Seni kaligrafi yang dipertontonkan masyarakat Pakandangan Barat sebagai aksesoris dan ornamen di Masjid al Fuadi, merupakan simbolisasi yang meliputi beberapa hal; (a) media interaksi antara sang hamba dan sang pencipta, Allah swt. Hal ini terbukti dengan ditampilkannya QS Ali Imran: 133 yang berisi pesan agar segera mohon ampun dari dosa-dosa; QS al Isra': 78 dan QS al Baqarah: 238-239 yang berisi seruan tentang intensitas menjaga waktu shalat dari pagi sampai malam; QS al Baqarah: 144 merupakan seruan menghadap kiblat; QS Ibrahim: 40-41 yang berisi doa agar diberikan generasi yang aktif mengerjakan shalat; QS al Ma'arij: 19-23 berisi pesan bahwa shalat dapat menjadikan seseorang tidak berkeluh-kesah. (b) motivasi ikhlas kepada pengunjung dan pengguna masjid dalam bertindak dan bertutur kata, termasuk dalam konteks ini pembangunan masjid. Oleh sebab itu, potongan QS al Taubah: 108 seakan ingin memproklamasikan kepada publik dengan potongan ayat tersebut bahwa Masjid al-Fuadi ini dibangun atas dasar motif ikhlas, mengingat masjid ini dibangun oleh seorang donatur tunggal yang bernama H. Fuad dari Desa Kapedi. Dengan demikian, masjid ini layak ditempati shalat, sebab suatu masjid yang dibangun atas dasar iklhas lebih layak di tempati shalat dari pada yang lain. Dengan dasar itu pulalah, potongan QS al Baqarah:114 ditampilkan dalam rangka memotivasi pengurus ta'mir dan pengunjung masjid agar senantiasa menyemarakkan dengan berbagai kegiatan keagamaan, sebab kata "kharabiha" dalam ayat tersebut tidak hanya berarti merobohkan, tetapi juga bisa mempunyai arti menelantarkan ( $\left.t a{ }^{\prime} t i l\right)$ masjid (al Sya'rawi, tt.: 322).

Adapun seni kaligrafi potongan ayat-ayat al Quran yang dijadikan ornamen dan aksesoris yang ditempel di rumah-rumah warga merupakan 
media edukatif. Pelajaran yang dapat dipetik dari kutipan ayat-ayat al Quran yang bertemakan tentang wisata religi ibadah haji, tidak saja mengingatkan orang agar melaksanakan haji bagi yang mampu, tetapi pesan terdalam, bahwa menunaikan ibadah tersebut dibutuhkan originalitas dan keikhlasan hati. Itulah sebabnya, mengapa kemudian ayat-ayat yang dikutip yaitu QS Ali Imran: 197 dan QS al Baqarah: 196. Kedua ayat tersebut, dimulai dari kalimat "Allah" dan dikahiri dengan kalimat "Allah" pula yang berarti dasar melaksanakan ibadah ini betul-betul karena Allah, bukan yang lain. Hal ini disebabkan ibadah haji mempunyai kontrol sosial (social control) yang sangat kuat. Membaca syahadat, shalat, puasa dan zakat misalnya, merupakan serangkaian ritus yang masuk di wilayah privat. Namun bagi ibadah haji, hampir dipastikan, kalau tidak malah harus, setiap orang yang akan bertandang ke Mekkah akan menggegerkan sanak-saudara bahkan satu desa sekaligus.

Adapun ayat-ayat yang merujuk pada QS al Baqarah: 158 tentang nuansa ibadah Sa'i dari Shofa ke Marwah untuk mengingatkan kembali sejarah berharga yang dialami oleh Siti Hajar sewaktu beliau lari-lari kecil mendaki dan menuruni bukit Shafa ke bukit Marwah untuk mencari setitik air buat anak yang baru dilahrikannya. Sikap dan tindakan semacam ini mengindikasikan keteguhan seorang ibu dalam mengasuh dan melindungi anak dari ancaman kematian (Fathurrosyid, 2008: 04).

Selain sebagai media edukatif, kutipan ayat-ayat religi ibadah haji di rumah warga menjadi simbolisasi struktur stratifikasi status sosial berdasarkan kekayaan material. Artinya, potongan ayat yang melekat di dinding rumah tersebut sudah bisa dipastikan bahwa penghuninya adalah orang yang sudah bertambah gelar berupa Pak Ajjih atau Buk Ajjih. Sebab, ibadah haji merupakan ibadah privilis yang tidak hanya butuh pada kekuatan fisik, seperti syahadat, shalat dan puasa, tetapi juga harus didukung dengan kekuatan material. Karena itu, wajar sekali jika ada orang yang emosinya meledak-ledak hanya gara-gara tidak dipanggil Pak Ajjih atau Buk Ajjih. Sebab predikat dan tambahan gelar sebagai Pak Haji atau Ibu Haji di mata orang Madura sungguh merupakan gelar yang mahal harganya. Predikat tersebut sebenarnya telah mengalami sofistifikasi dari sesuatu yang sakral ke wilayah profan, seperti pakai peci putih, ganti nama dan pakaian kearab-araban sepulang dari tanah suci. Dengan demikian, potongan ayat tersebut merupakan simbol stratifikasi dan popularitas sosial (Fathurrosyid, 2016: 11).

Tidak jauh berbeda dengan simbolisasi kutipan ayat-ayat religi ibadah haji, kutipan potongan ayat yang ada di dinding rumah warga Pakandangan 
tentang tema pernikahan juga sebagai media interaksi yang bersifat edukatif bagi pembacanya. Potongan ayat al Quran yang seringkali dijumpai di setiap resepsi pernikahan tertempel indah di dinding rumah warga, terutama mempelai perempuan, yaitu QS al Nisa': 19. Hal ini disebabkan kaum perempuan selalu mengalami tindakan eksploitatif, diskriminatif dan anarkis, baik secara fisik maupun psikologis. Fakta yang terjadi di lapangan, seroang ibu kerap kali terpaksa harus bisa menekan dan menahan rasa galau, sakit hati dan kegetiran hidupnya terhadap perilaku yang dipertontonkan sang suami. Demi atas nama agama, cinta dan kasih-sayang, perlakuan kasar seorang suami, baik fisik maupun psikologis, semisal pemukulan, perselingkuhan, nikah di bawah tangan (nikah sirri) dan kasus poligami, seorang ibu harus berani menyimpan rapat-rapat bitter diary-nya, bahkan kegetiran itu hingga di bawa mati, tanpa ada pihak manapun yang mengetahuinya.

Di mata perempuan, yang namanya percekcokan keluarga, termasuk penganiayaan yang mereka alami, bukan saja dipandang tabu untuk diperbincangkan, apalagi dipublikasikan, tetapi itu juga dikarenakan secara struktural kemungkinan untuk mengambil tindakan yang melawan arus bukanlah hal yang mudah. Di wilayah pedesaan dan di kalangan keluarga golongan menengah ke bawah, sering terjadi kaum perempuan terpaksa harus menalan secara mentah-mentah beban penderitaan mereka karena adanya ketergantungan yang tinggi pada suami. Kaum perempuan yang tak bekerja dan menjadi ibu rumah tangga dengan dalih demi masa depan anakanak dan dirinya, mau tidak mau, harus bersikap pasrah terhadap kelakuan sadis-anarkis suami. Dengan kutipan potongan ayat al Quran di atas, warga Pakandangan Barat hendak menyampaikan pesan, bahwa tugas seorang suami harus memperlakukan isterinya dengan baik (bi al ma'ruf), tidak hanya di atas ranjang, tetapi juga di luar ranjang sekalipun.

Resepsi fungsional. Potongan ayat-ayat al Quran yang dijadikan sebagai instrumen mistis dan ritus oleh masyarakat Pakandangan Barat, misalnya dijadikan alat untuk membuka gembok, melemahkan kekuatan lawan, melariskan perniagaan, pengusir roh jahat dan tujuan tertenu lainnya, menunjukkan bahwa mereka sedang menunjukkan kebenaran mukjizat al Quran berdasarkan logika epistiemologi pragmatis. Bagi penganut paham pragmatis, bahwa ujian kebenaran adalah berdasarkan pada manfaat (utility), kemungkinan dikerjakan (workability) atau akibat yang memuaskan sehingga dapat dikatakan bahwa pragmatisme adalah suatu aliran yang mengajarkan bahwa yang benar ialah apa yang membuktikan dirinya sebagai benar dengan 
perantaraan akibat-akibatnya yang bermanfaat secara praktis. Apa yang diartikan dengan benar bagi mereka adalah yang berguna (usefull) dan yang diartikan salah adalah yang tidak berguna (useless).

Selain menunjukkan kemukjizatan al Quran dengan menggunakan logika pragmatis, resepsi fungsional al Quran juga mempunyai simbol-simbol tersendiri, yaitu media silaturrahmi yang berdimensi solidaritas sosial. Pembacaan al al Quran pada acara pelet kandung, rokat pakarangan dan khtamil quran, merupakan serangkain ritus yang mempunyai nilai filosofis sebagai media jejaring sosial. Hal ini disebabkan, setiap kegiatan upacara ritual atau slametan adalah sebuah kegiatan yang melibatkan semua unsur-unsur masyarakat di dalam lingkungan bertetangga. Partisipasi masyarkat di dalam upacara ritual atau slametan menggambarkan adanya tindakan harmonisasi sosial, keteraturan sosial dan kerukunan sosial, sebab semua anggoata masyarakat dalam lingkaran bertetangga tersebut dalam suasana yang sama dan juga menikmati makanan yang hampir sama sehingga inilah suatu wujud dari konsepsi Jawa mengenai slamet, rukun dan harmoni. Dengan demikian, ritus yang diadakan oleh masyarakat Pakandangan dengan melibatkan kehadiran al Quran tidak saja sebagai agenda memperbanyak pahala, sebagaimana tuntunan Nabi, tetapi juga sebagai wadah menciptakan harmonisasi sosial.

\section{Tradisi Resepsi al Quran: Sorot Balik Diskursus Ilmu al Quran dan Tafsir}

Masyarakat Pakandangan Barat mempunyai cara tersendiri dalam mengekspresikan bukti kecintaannya pada kitab sucinya, al Quran. Apa yang mereka lakukan dengan cara resepsi eksegetis, estetis dan fungsional adalah bukti nyata adanya varian resepsi yang diekpresikan oleh mereka. Al Quran di mata masyarakat Pakandangan Barat, selain diposisikan sebagai kitab yang harus dibaca dan dipahami, juga menjadi kitab yang harus dipraktikkan sebagai solusi terhadap problematika yang sedang terjadi. Tipologi resepsi yang dipertontonkan oleh warga Pakandangan Barat merupakan hasil refleksi dari pemahaman mereka terhadap ayat-ayat al Quran dengan kondisi sekitar. Dengan demikian, tiga resepsi tersebut dalam diskurus ilmu al Quran dan tafsir dapat dikategorikan sebagai tafsir realis dan transfomatif, yaitu tafsir yang mampu berdialektika dan bernegosiasi dengan konteks sosial tertentu dan isu-isu global yang sedang berkembang di masyarakat.

Pemahaman terhadap ayat-ayat al Quran yang berdialektika dengan kondisi sosial, menurut Hasan Hanafi merupakan tafsir humanis. Hal ini 
disebabkan al Quran merupakan kitab suci yang diturunkan oleh Allah untuk seluruh ummat manusia lintas, tempat waktu dan zaman. Karena itu, menurut Hasan Hanafi, keberanian untuk menafsirkan ayat-ayat al Quran yang berpihak pada realitas dan problem sosial kehidupan masyarakat, merupakan kebutuhan mendesak untuk segara diaplikasikan. Salah-satu pertimbangan dan asumsi dasar hermeneutika tafsir realis, solutif dan transformatif yang digagas Hasan Hanafi, disebabkan suatu teks nyaris tidak bisa dilepaskan dari muatan-muatan subjekif dan prejudice-prejudice kultural yang melingkari horizon penafsir. Oleh sebab itu, mengedepankan aspek ideal moral dari pada legal formal merupakan tindakan humanis dalam dunia penafsiran. Dengan kata lain, keberpihakan kepada problem sosial dan isu-isu yang terjadi di masyarakat harus lebih diutamakan dari pada yang lain.

Kecuali itu, terkait dengan pemaknaan ayat al Quran, para penggiat dan pemerhati ilmu al Quran mengusulkan tiga level makna suatu pesan yang inherent dalam ayat-ayat al Quran, yaitu:

1. Makna yang hanya menunjuk kepada bukti atau fakta sejarah yang tidak bisa diinterpretasikan secara metaforis.

2. Makna yang menunjuk kepada bukti dan fakta sejarah yang bisa diinterpretasikan secara metaforis.

3. Makna yang bisa diperluas berdasarkan signifikansi yang diungkap dari konteks sosio-kultural di mana teks itu muncul (Zayd, 1994: 124-146).

Berdasarkan teori yang demikian, maka tipologi resepsi yang dipertontonkan oleh masyarakat Pakandangan Barat dapat dikategorikan pada level makna yang ketiga. Pemahaman dan pemaknaan yang mereka lakukan terhadap ayatayat al Quran merupakan pemahaman yang diperluas dari konteks sosial di mana ayat itu diturunkan dalam rangka untuk memberikan solusi terhadap problematika yang sedang dihadapi.

Sekalipun demikian, resepsi yang dilakukan oleh masyarakat Pakandangan Barat, jika menggunakan tipologi para pembaca dan pecinta al Quran yang digagas oleh Fazlurrahman tidak termasuk sebagai pecinta kritis (critical lovers) (Essack, 2002: 1-10). Masyarakat Pakandangan Barat dalam mengekspresikan kecintaannya pada al Quran masih sebatas tahap pecinta tidak kritis (uncritical lovers) dan pecinta ilmiyah (ilmiyah lovers). Interaksi yang ditunjukkan oleh masyarakat Pakandangan, terutama dalam resepsi estetis dan fungsional menunjukkan interaksi yang bersifat fanantisme dan membabi buta. Mereka sekedar membaca dan mengagumi tanpa memahami secara utuh pesan-pesan dari setiap ayat yang mereka baca dan mereka kutip, sebagaimana yang telah 
dijabarkan secara detail di atas.

\section{Simpulan}

Kitab suci al Quran sejatinya merupakan kitab yang berisi ajaran-ajaran moral untuk menuntun manusia ke jalan yang lurus. Hanya saja, ketika al Quran dikonsumsi oleh publik, kitab tersebut mengalami pergeseran paradigma sehingga diperlakukan, diresepsi dan dieskpresikan berbeda sesuai dengan keyakinan masing-masing. Ekspresi tersebut, tentu merupakan indikator konkrit bahwa al Quran merupakan kitab suci yang selalu selaras dengan zaman, lintas tempat, ras, suku dan bangas (shalihun li kulli zamanin wa makanin).

Model dan gaya resepsi tersebut bahkan kini terus diekspresikan, dilestarikan dan diabadikan oleh masyarakat di Sumenep. Mereka meresepsi al Quran dengan cara dibaca, dipahami dan ditafsirkan (resepsi eksegetis). Kecuali itu, al Quran juga diresepsi dan dikekspresikan sebagai kitab suci yang memuat unsur keindahan sehingga dijadikan aksesoris masjid dan dinding rumah (resepsi estetis), bahkan tidak jarang sekali masyarakat Sumenep menjadikan al Quran sebagai kitab suci yang mempunyai kekuatan magic, sehingga dijadikan sebagai instrumen mistis dan ritus (resepsi fungsional).

Bentuk-bentuk resepsi yang "ditampilkan" oleh masyarakat Sumenep tersebut dalam diskurus ilmu al Quran dan tafsir dapat dikategorikan sebagai tafsir realis dan transfomatif. Hal ini tentu jika dilihat dari simbolisasi resepsi struktur luar (surface structure) yang menunjukkan sebagai masyarakat yang religius. Sementara struktur dalamnya (deep structure) memuat pesan-pesan solidaritas, kohesivitas dan harmonisasi sosial, media edukatif, media stratifikasi struktur sosial dan sebagai bukti adanya struktur logika pragmatis tentang kemukjizatan al Quran.

\section{Daftar Pustaka}

Al Baihaqi. 1408. Dala'il al-Nubuwwah. Juz II. Kairo: Dar al-Kutb al'Ilmiyyah.

Al Bukhari. 1407. Sahih al-Bukhari. Juz VII. Kairo: Dar al-Syu'ub.

Al Dzahabi, Muhammad Husein. t.th. al-Tafsir wa al-Mufassirun. Jilid I. Beirut: Dar al-Fikr.

Al Qurtubi, Syamsuddin. 1423. al-Jami' li Ahkam al Qur'an. Juz XVII. Riyad: Dar Alam al-Kutb. 
Al Suyuti, Jalal al Din. t.th. al-Itqan fi 'Ulum al Qur'an.Vol. 2. t.tp: Dar alfikr.

Al Sya'rawi, Syaikh Mutawalli. t.th. Tafsir al-Sya'rawi. Juz I. Kairo: Dal Qalam.

Arikunto, Suharsimi. 1993. Prosedur Penulisan; Suatu Pendekatan Praktik. Yogyakarta: Rineka Cipta.

Annisa, Fitri. "Harmoni dalam Keragaman; Konstruksi Perdamaian dalam Relasi Islam, Katolik, Sunda Wiwitan di Kali Minggir dan Nagarherang Kabupaten Tasik Malaya”, dalam Harmoni; Jurnal Multikultural $\mathcal{E}$ Multireligius, Vol. 11, Nomor 3, Juli - September 2012.

Bungin, (ed.), Burhan. 2006. Analisis Data Penelitian Kualitatif; Pemahaman Filosofis dan Metodologis ke Arah Penguasaan Model Aplikasi. Jakarta: Raja Grafindo Persayad.

Darraz, Muhammad Abdullah. 1985. al-Naba' al-Azim; Nazarat Jadidah fi al Qur'an. Juz I. Kairo: Dar al-Tsaqafah.

Esack, Farid. 2002. The Qur'an: A Short Introduction. England: Oneworld Publication.

Fathurrosyid. 29 Nopember, 2008. Haji di Mata Orang Jawa Timur. Radar Madura: 4.

Fathurrosyid. 06 Oktober, 2015. Simbolisasi Haji di Madura. Koran Madura: 11.

Iser, Wolfgang. 1978. The Act of Reading; A Theory of Aesthetic Response. Baltimore: John Hopkins University Press.

Kodiran, "Kebudayaan Jawa" dalam Koentjaraningrat, Manusia dan Kebudayaan di Indonesia (Jakarta: Jambatan, 1975.

Mansyur, dkk. M. 2007. Metodologi Penelitian Living Qur'an dan Hadis. Yogyakarta: TH. Press.

Moleong, Lexy J.. 2009. Metodologi Penelitian Kualitatif. Bandung: Remaja Rosdakarya. 
Pradopo, Rachmat Djoko. 2007. Beberapa Teori Sastra; Metode Kritik dan Penerapannya. Yogyakarta: Pustaka Pelajar.

Pringgawidagda, Suwarna. 2003. Upacara Tingkeban. cet ke-1. Yogyakarta: Adicita Karya Nusa.

Rahman, Yusuf. 2004. "Kritik Sastra dan Kajian al Qur'an” dalam Pengantar Kajian al Qur'an. Jakarta: Pustaka al-Husain.

Ratna, Nyoman Kutha. 2009. Teori, Metode, dan Teknik Penelitian Sastra. Yogyakarta: Pustaka Pelajar.

Rofiq, Ahmad. 2004. "Pembacaan yang Atomistik terhadap al Qur'an; Antara Penyimpangan dan Fungsi”, dalam Jurnal Studi al Qur'an dan Hadits, UIN Sunan Kalijaga, Yogyakarta, Vol. 4, No. I, Januari.

Surakhmad, Winarno. 1990. Pengantar Penelitian Ilmiah; Dasar dan Metode Teknik. Bandung: Tarsio.

Syam, Nur. 2009. Mazhab-Mazhab Antropologi. Yogyakarta: LKiS.

Syuhbah, Abu. 1423. al-Madkhal li Dirasat al Qur'an. Kairo: Maktabah alSunnah.

Tha'imah, Shabir . 1399. Hadza al Qur'an; Qishshat al-Dzikr al-Hakim Tadwinan wa Tafkiran. Beirut: Dar al-Jil.

Zayd, Nasr Hamid Abu. 1994. Naqd at-Khitab al-Dini. Kairo: Shina' Ii alNashr.

Ziher, Ignaz Gold. 1403. Mazahib al-Tafsir al-Islami. Beirut: Dar Iqra'. 